\title{
Water Use Efficiency, Yield and Crop Coefficient (Kc) of Groundnut Crop at Different Water Regimes under Agro Climatic Condition of Raichur, Karnataka, India
}

\author{
K.T. Aruna*, U. Satish Kumar, G.V. Srinivasa Reddy, \\ A. Amare Gowda and U.K. Shanwad \\ *Corresponding author
}

\section{A B S T R A C T}

\begin{tabular}{|l|}
\hline Ke y w o r d s \\
Crop coefficient, \\
AMHC, Water use \\
efficiency, Crop \\
yield, Water \\
regimes.
\end{tabular}

The pot experiment was carried out during September 2015 to January 2016 at instructional farm, College of Agricultural Engineering, UAS Raichur under rain shelter to study the effect of different water regimes, (i.e. $\mathrm{T}_{1}: 100, \mathrm{~T}_{2}: 90, \mathrm{~T}_{3}: 80, \mathrm{~T}_{4}: 70, \mathrm{~T}_{5}: 60$ and $\mathrm{T}_{6}: 50$ ) per cent of water application with available moisture holding capacity on grain yield and water use efficiency. Completely Randomized block design with four replications was used in this study. The results showed that there was significant difference between the yield and (WUE) under different levels of irrigation. The total irrigation water applied were (i.e., 211.98, 243.02, 225.78, 155.09, 135.51 and $105.62 \mathrm{~mm} / \mathrm{plant}$ ) under different water regime treatments $(100,90,80,70,60$ and $50 \%)$ of available moisture holding capacity (AMHC) respectively. Grain yield productions under different treatments were $106.25,171.25,127.50,75,55$ and $40.75 \mathrm{~g} / \mathrm{plant} /$ pot at 100, 90, 80, 70, 60 and 50 per cent of AMHC respectively. The results showed that water use efficiency (WUE) at different treatments were $0.50,0.70,0.56,0.48,0.41$ and $0.39 \mathrm{~g} / \mathrm{mm}$ for $(100,90,80,70$, 60 and $50 \%$ ) per cent of AMHC respectively. Therefore, the $90 \%$ of AMHC treatment (T2) is recommended for groundnut irrigation for water saving. The comparison of actual crop coefficient that obtained by water balance technic in experiment and crop coefficient $\left(\mathrm{K}_{\mathrm{c}}\right)$ values of groundnut for different crop growth stages were selected based on the values suggested by FAO (Allen et al., 1998) are similar in the treatment of $90 \%\left(\mathrm{~T}_{2}\right)$ of the AMHC. Furthermore, the result showed that the treatment of 90 per cent of Available moisture holding capacity $\left(\mathrm{T}_{2}\right)$ seemed to be better adapted to product a high crop yield with acceptable yield coupling with water use efficiency in this region.

\section{Introduction}

Water resources were considered bountiful so far, but have now come under increasing pressure, primarily due to burgeoning population and competing demand from other water consuming sectors. About, 75 to $80 \%$ of the available freshwater resource is used for agricultural production in many parts of the World (FAO, 2016). According to the nature resources and economic condition of the region, water-saving agriculture is the most effective way to solve the problem in water shortage in agriculture and to make sustainable use in water resources and increase the water use efficiency of crops. Groundnut crop (Arachis hypogaea L.) is one of the leading oilseed crops, as its seeds contain high amounts of edible oil (43-55\%) and protein $(25-28 \%)$ on a dry seed basis (Savage and keenam 1994). Even though it is a fairly drought-tolerant, production fluctuates 
considerably as a result of rainfall variability. This is because farmers are afraid of low yields due to scarcity of water during the lean season. Moreover there is no information to help farmers to manage this scarce resource called water during drought in order to optimise yields in the lean season

Furthermore, to calculate groundnut crop evapotranspiration (ETc), there is need to multiply the crop co-efficient $(\mathrm{Kc})$ by the reference evapotranspiration (ETo). However, over the years, $\mathrm{Kc}$ is selected from 1.05 for both the developmental and mid-season stages.

But Allen et al., (1998) reported Kc values of 1.05 and 0.70 for both the mid-season and late season stages respectively. Therefore, there is the need to determine the $\mathrm{Kc}$ values for groundnut grown in Agro climatic condition of Raichur, Karnataka at the different developmental stages for accurate estimation of crop evapotranspiration (ETc).

The study thus seeks to determine the $\mathrm{Kc}$ for the various growth stages and also investigate the effect of deficit irrigation on the growth and yield of groundnut.

\section{Materials and Methods}

\section{Study area}

The study was conducted at the instructional farm, College of Agricultural Engineering, UAS Raichur. It is situated in North-Eastern Dry zone (Zone 2) of Karnataka at $16^{\circ} 12^{\prime} \mathrm{N}$ latitude and $77^{\circ} 20^{\prime} \mathrm{E}$ longitude with an altitude of 389 meters above the mean sea level. The temperature and relative humidity of the study area were $14.8-36.2^{\circ} \mathrm{C}$ and 78-94 per cent respectively. While, the soil type and annual rainfall are sandy clay loam and 540$800 \mathrm{~mm}$ respectively.

\section{Experimental design and procedure}

In this study, groundnut seeds (Kadiri-9) were grown in containers (Plastic Pots) and placed under a rain shelter. Completely Randomised Design (CRD) with four replications (R1-R4) and six treatments (T1-T6 two samples per each treatment) was used. In all there were fourty eight (48) treatment combinations.

\section{Soil characteristics of the location}

The experiment was laid out on red soil. Composite soil sample was collected from the experimental site from top $30 \mathrm{~cm}$ depth before initiation of experiment. The soil was air dried, powdered and allowed to pass through $2 \mathrm{~mm}$ sieve and was analyzed for physical (viz., textural composition and bulk density) and chemical properties (available $\mathrm{N}, \mathrm{P}, \mathrm{K}$, $\mathrm{EC}$ and $\mathrm{pH}$ ) were determined using the standard procedures.

Under the textural classification, the soil was found to be sandy clay loam. The values obtained along with the methods employed for their estimation are furnished in Table 1.

\section{Soil moisture constants}

The soil samples were collected based on the standard procedure. The field capacity (FC) and permanent wilting point (PWP) of the soil were determined using pressure plate apparatus. The field capacity of the soil was determined by keeping saturated soil in extractor chamber under the pressure of 0.33 bars. The permanent wilting point of soil was determined by keeping saturated soil in extractor chamber under the pressure of 15 bars. The moisture content at field capacity and permanent wilting point are presented in Table 1.

$\mathrm{AMHC}=\frac{(\mathrm{FC}-\mathrm{PWP})}{100} * \gamma \mathrm{d} *$ volume of pot 3.1 
Where, $\mathrm{AMHC}=$ Available moisture holding capacity; FC = field capacity $(\%)$; $\mathrm{PWP}=$ permanent wilting point $(\%) ; \mathrm{BD}=$ bulk density $\left(\mathrm{g} \mathrm{cm}^{-3}\right)(\gamma \mathrm{d})$.

The soil textural class was sandy clay loam within the soil profile considered. The values of FC, PWP and AMHC were $26.0 \%, 11.4 \%$ and $2000 \mathrm{~g}$ respectively, while the bulk density was $1.4 \mathrm{~g} \mathrm{~cm}^{-3}$ and volume of the pot is $9740 \mathrm{cc}$.

\section{Irrigation water application}

Irrigation water was applied to the treatment T1 crop upto $26 \%$ of field capacity reached (12300 g of pot weight), for treatment T2 when $10 \%$ depletion of the available soil moisture occurred within the crop root zone (Table 2).

\section{Growth stages}

In this experiment, four growth stages were examined, namely initial, developing, mid and late stages. Treatments were then given at these various stages.

\section{Treatments}

At the end of every day, available moisture holding capacity (AMHC) was determined for each treatment and the corresponding volume or amount of water was given. These were: $\mathrm{T} 1=100 \%$ of $\mathrm{AMHC}, \mathrm{T} 2=90 \%$ of $\mathrm{AMHC}$, $\mathrm{T} 3=80 \%$ of $\mathrm{AMHC}, \mathrm{T} 4=70 \%$ of $\mathrm{AMHC}$, $\mathrm{T} 5=60 \%$ of $\mathrm{AMHC}$ and $\mathrm{T} 5=50 \%$ of AMHC.

\section{Data collection}

The following data were collected during the research i.e. crop evapotranspiration (ETc) water applied for crop at different growth stages, plant height, leaf area index, SPAD values, number of leaves per plant, crop yield, crop co-efficient $(\mathrm{Kc})$ and water use efficiency.

\section{LAI (Leaf Area Index)}

It is the total green leaves occupied per unit of land surface (Ashley et al., 1965). Leaf area index (LAI) was measured with an AccuPAR 80 ceptometer (Decagon Devices, Inc., Pullman, WA, USA) between 11:30 am and $3: 30 \mathrm{pm}$. The ceptometer contains 80 individual quantum sensors on the probe and automatically calculate LAI based on PAR readings from the ground to the top of the canopy. The observations were recorded at initial, developing, mid and late stages for each plant.

\section{SPAD value}

Leaf chlorophyll content was also determined by light absorbance in the red and infrared light with a chlorophyll meter (SPAD-502, Minolta France SA, Currieres-Sur-Seine, France) as per the procedure followed by Hervey et al., (2001) as well as Teng et al., (2004) SPAD was used to measure the chlorophyll meter readings.

Chlorophyll meter observations were expressed as SPAD readings. The observations were recorded at initial, developing, mid and late stages for each plant.

\section{Plant height and number of leaves}

Plant height for each plant was determined by measuring the length of the plant from the base to the apex of the plant and also number of leaves for each plant for initial, developing, mid and late stages of groundnut crop was recorded.

\section{Yield components}

Plants from each pot were harvested and developed pods were separated, soil particles adhered to the pods was removed and sun dried. The pod weight (g/plant/pot) was recorded for every treatment. 
Determination of crop co-efficient (Kc), Crop evapotranspiration (ETc) and reference evapotranspiration (ETo)

The crop water requirement (ETc) is defined as the depth or amount of water needed to meet the water loss through evapotranspiration and it is given by the formula, crop coefficient for the four growth stages were determined (Allen et al., 1998),

$K c=\frac{E T c}{E T o}$

Where,

$\mathrm{K}_{\mathrm{c}}$ : Crop coefficient [dimensionless]

$\mathrm{ET}_{\mathrm{c}}$ : Crop evapotranspiration $\left[\mathrm{mm} \mathrm{d}^{-1}\right]$

$\mathrm{ET}_{\mathrm{o}}$ : Reference crop evapotranspiration $[\mathrm{mm}$ $\left.\mathrm{d}^{-1}\right]$

\section{Reference crop Evapotranspiration (ETo)} was also calculated by the formula

The $\mathrm{ET}_{\mathrm{o}}$ estimation pertaining to study area was calculated using Standardized Reference Evapotranspiration Equation recommended by the Food and Agricultural Organizations, Irrigation and Drainage Paper No.56 (FAO). Following standard procedure and formula.

The required data for ETo estimation was obtained from main agricultural research station (MARS) located in Raichur campus. Thus ETo calculated on daily basis during stipulated crop period of groundnut crop $\left(24^{\text {th }}\right.$ Sep to $20^{\text {th }}$ Jan 2016) was summarised on weekly, monthly and crop growth stage wise.

$E T_{0}=\frac{0.408 \Delta\left(R_{n}-G\right)+\gamma \frac{900}{T+273} U_{2}\left(e_{s}-e_{a}\right)}{\Delta+\gamma\left(1+0.34 U_{2}\right)}$

Where,
$\mathrm{ET}_{\mathrm{o}}=$ Reference evapotranspiration $(\mathrm{mm}$ day $^{-1}$ )

$G=$ soil heat flux density $\left(\mathrm{MJ} \mathrm{M}^{-2}\right.$ day $\left.^{-1}\right)$

$R_{n}=$ net radiation $\left(\mathrm{MJ} \mathrm{M}^{-2} \mathrm{day}^{-1}\right)$ (used sunshine hours)

$T=$ Mean daily air temperature $\left({ }^{0} \mathrm{C}\right)$

$\gamma=$ Psychrometric constant $\left(\mathrm{kPa}^{0} \mathrm{C}^{-1}\right)$

$\Delta=$ Slope of saturation vapour pressure function $\left(\mathrm{kPa}^{0} \mathrm{C}^{-1}\right)$

$e_{s}=$ saturation vapour pressure at air temperature $\mathrm{T}(\mathrm{kPa})$

$e_{a}=$ actual vapour pressure at dew point temperature $(\mathrm{kPa})$

$U_{2}=$ average daily wind speed at $2 \mathrm{~m}$ height $\left(\mathrm{m} \mathrm{sec}{ }^{-1}\right)$

\section{Water use efficiency}

The water use efficiency of each treatment was computed using the following formula for different levels of available moisture holding capacity. (Sinclair et al., 1984)

$=\frac{Y}{W R}$

Where,

$\mathrm{e}_{\mathrm{u}}=$ Water use efficiency, $\mathrm{g} \mathrm{mm}^{-1}$

$\mathrm{Y}=$ Crop yield, $\mathrm{g}$

$\mathrm{WR}=$ Total amount of water used in the field, $\mathrm{mm}$

\section{Statistical analysis}

The data on the observations with respect to crop physiological responses made and characters studied were statistically analyzed 
using Completely Randomised Design. Wherever, the results are significant, the critical difference at 1 per cent level was worked out and presented in respected tables. The data were analyzed by using 'SPSS' software.

\section{Results and Discussion}

\section{Leaf area}

From Table 3, the leaf area index for the various treatments showed significant differences at $10 \%$ between them 25 days after sowing, though variations or differences were observed in the order of T2> T3> T1> T4> T5> T6. Furthermore, at the end of harvesting stage there were significant differences between the various treatments applied. The table shows that T2 had the highest mean leaf area index while the least was T6. This could be due to water stress and could be said that reduction of moisture reduces the rate of leaf expansion as a mechanism to obviate the effect of moisture stress and this is supported by Norman et al., (1995).

Yield (Number of pods /plant, yield and total dry matter)

The yield data taken from the studies can be seen in Table 4. For the mean number of pods, treatment $\mathrm{T} 2$ had the highest and it was significantly different from $\mathrm{T} 1 \& \mathrm{~T} 3$.

It could therefore be said that a slight reduction of water requirement of groundnut does not significantly affect the number of pods formed. However, above 20\% water stress affects number of pods per plant. For total pod yield per plant, differences existed between the treatments applied. However T1\& T3 showed no significant differences while T4 \& T5 also showed no significant difference, while T2 were significantly different from T1 \& T3. It could be said that for a significant reduction of pod yield per plant to be seen for more than 20 per cent of water deficit. Groundnut plant under T2 treatment had the highest number of pods and pod yield per plant and this was significantly different from $\mathrm{T} 1, \mathrm{~T} 3, \mathrm{~T} 4, \mathrm{~T} 5$ and $\mathrm{T} 6$ $(\mathrm{T} 2>\mathrm{T} 3>\mathrm{T} 1>\mathrm{T} 4>\mathrm{T} 5>\mathrm{T} 6)$. This order suggests that availability of the right amount of water enhances the development and final yield of groundnut as reduction imposes stress thus making the plants unable to efficiently make use of available nutrients for growth and yield.

\section{Water use efficiency}

The water use efficiency for groundnut crop as influenced by different soil moisture stress levels is presented in Table 5. The water use efficiency varied from $0.70 \mathrm{~g} \mathrm{~mm}^{-1}$ (10 per cent depletion of soil moisture stress level) to $0.39 \mathrm{~g} \mathrm{~mm}^{-1}$ (50\% depletion of soil moisture stress level) Among different soil moisture stress treatments, plant receiving water at 10 per cent depletion of soil moisture stress level treatment recorded the highest water use efficiency $\left(0.7 \mathrm{~g} \mathrm{~mm}^{-1}\right)$ which is on decreasing trend for 20 per cent depletion of soil moisture stress level $\left(0.56 \mathrm{~g} \mathrm{~mm}^{-1}\right)$, no soil moisture stress level $\left(0.5 \mathrm{~g} \mathrm{~mm}^{-1}\right), 30$ per cent depletion of soil moisture stress level $\left(0.48 \mathrm{~g} \mathrm{~mm}^{-1}\right), 40$ per cent depletion of soil moisture stress level $\left(0.41 \mathrm{~g} \mathrm{~mm}^{-1}\right)$ and 50 per cent depletion of soil moisture stress level $\left(0.39 \mathrm{~g} \mathrm{~mm}^{-1}\right)$.

\section{Crop co-efficient (Kc), reference evapotranspiration evapotranspiration

and crop

From Table 6, the seasonal $\mathrm{Kc}$ value for groundnut crop grown in Raichur it is situated in North-Eastern Dry zone (Zone 2) of Karnataka was found to be between 0.440.60 . 
Table.1 Soil characteristics of the experimental plot at Raichur

\begin{tabular}{|c|l|c|l|}
\hline Soil characteristics & \multicolumn{1}{|c|}{ Particulars } & Composition & \multicolumn{1}{c|}{ Method } \\
\hline \multirow{4}{*}{ Textural composition } & Sand $(\%)$ & 61.8 & \\
& Silt $(\%)$ & 17.4 & Piper (1966) \\
& Clay $(\%)$ & 20.8 & \\
\hline \multirow{5}{*}{ Chemical composition } & Available $\mathrm{N}(\mathrm{kg} / \mathrm{ha})$ & 285 & Jackson (1967) \\
\cline { 2 - 4 } & Available $\mathrm{P}_{2} \mathrm{O}_{5}(\mathrm{~kg} / \mathrm{ha})$ & 39.5 & Jackson $(1967)$ \\
\cline { 2 - 4 } & Available $\mathrm{K}_{2} \mathrm{O}(\mathrm{kg} / \mathrm{ha})$ & 224.2 & Jackson $(1967)$ \\
\cline { 2 - 4 } & pH & 6.85 & Jackson (1967) \\
\cline { 2 - 4 } & EC $(\mathrm{ds} / \mathrm{m})$ & 0.139 & Jackson (1967) \\
\hline \multirow{3}{*}{ Physical characters } & Bulk density $\left(\gamma_{\mathrm{d}}\right)\left(\mathrm{g} / \mathrm{cm}^{3}\right)$ & 1.4 & Richards (1954) \\
\cline { 2 - 4 } & Field capacity $(\%)$ & 26.0 & Pressure plate \\
\cline { 2 - 4 } & Permanent wilting point $(\%)$ & 11.4 & Pressure plate \\
\hline
\end{tabular}

Table.2 Pot weight of different Available Moisture Holding Capacity (AMHC) for different treatments

\begin{tabular}{|l|l|l|l|l|l|l|}
\hline AMHC $(\%)$ & $100 \%\left(\mathrm{~T}_{1}\right)$ & $90 \%\left(\mathrm{~T}_{2}\right)$ & $80 \%\left(\mathrm{~T}_{3}\right)$ & $70 \%\left(\mathrm{~T}_{4}\right)$ & $60 \%\left(\mathrm{~T}_{5}\right)$ & $50 \%\left(\mathrm{~T}_{6}\right)$ \\
\hline Pot weight & 12300 & 12100 & 11900 & 11700 & 11500 & 11300 \\
$(\mathrm{~g})$ & $\mathrm{MC}=26 \%$ & $\mathrm{MC}=23.4 \%$ & $\mathrm{MC}=20.8 \%$ & $\mathrm{MC}=18.2 \%$ & $\mathrm{MC}=15.6 \%$ & $\mathrm{MC}=13 \%$ \\
\hline
\end{tabular}

Table.3 Leaf area index per plant of groundnut at different growth stages as influenced by different Available Moisture Holding Capacity (AMHC)

\begin{tabular}{|c|c|c|c|c|c|c|}
\hline Treatments & $\begin{array}{c}\mathbf{T}_{\mathbf{1}}=100 \% \\
\text { of AMHC }\end{array}$ & $\begin{array}{c}\mathbf{T}_{\mathbf{2}}=90 \% \\
\text { of AMHC }\end{array}$ & $\begin{array}{c}\mathbf{T}_{\mathbf{3}}=80 \% \\
\text { of AMHC }\end{array}$ & $\begin{array}{c}\mathbf{T}_{\mathbf{4}}=70 \% \\
\text { of AMHC }\end{array}$ & $\begin{array}{c}\mathbf{T}_{\mathbf{5}}=60 \% \\
\text { of AMHC }\end{array}$ & $\begin{array}{c}\mathbf{T}_{\mathbf{6}}=50 \% \\
\text { of AMHC }\end{array}$ \\
\hline Initial stage & 0.56 & 0.91 & 0.79 & 0.62 & 0.42 & 0.33 \\
\hline Developmental stage & 2.00 & 2.47 & 2.25 & 1.88 & 1.17 & 1.04 \\
\hline Mid stage & 3.34 & 3.78 & 3.49 & 3.32 & 3.11 & 2.18 \\
\hline At harvest & 2.55 & 3.04 & 2.76 & 2.32 & 2.15 & 1.78 \\
\hline
\end{tabular}

Table.4 Effect of Different available moisture holding capacity levels on number of pods, yield, kernel weight and total dry matter per plant

\begin{tabular}{|c|c|c|c|c|c|c|}
\hline Treatments & $\begin{array}{c}\mathbf{T}_{\mathbf{1}} \\
\mathbf{1 0 0 \%} \\
\text { of } \\
\text { AMHC }\end{array}$ & $\begin{array}{c}\mathbf{T}_{\mathbf{2}}=90 \% \\
\text { of } \\
\text { AMHC }\end{array}$ & $\begin{array}{c}\mathbf{T}_{\mathbf{3}}=80 \% \\
\text { of AMHC }\end{array}$ & $\begin{array}{c}\mathbf{T}_{\mathbf{4}}=70 \% \\
\text { of AMHC }\end{array}$ & $\begin{array}{c}\mathbf{T}_{5}=60 \% \\
\text { of AMHC }\end{array}$ & $\begin{array}{c}\mathbf{T}_{\mathbf{6}}=50 \% \\
\text { of AMHC }\end{array}$ \\
\hline $\begin{array}{c}\text { Number of pods } \\
\text { /plant }\end{array}$ & 33 & 47 & 37 & 26 & 22 & 18 \\
\hline Yield (g/plant) & 106.25 & 171.25 & 127.50 & 75.00 & 55.00 & 40.75 \\
\hline $\begin{array}{c}\text { Total dry matter } \\
\text { (g/plant) }\end{array}$ & 73.50 & 90.06 & 80.75 & 65.56 & 58.25 & 41.19 \\
\hline
\end{tabular}


Table.5 Water use efficiency of groundnut crop under different levels of available moisture holding capacity

\begin{tabular}{|c|c|c|c|c|c|c|}
\hline Treatments & $\begin{array}{c}\mathbf{T}_{\mathbf{1}}=100 \% \\
\text { of AMHC }\end{array}$ & $\begin{array}{c}\mathbf{T}_{\mathbf{2}}=90 \% \\
\text { of AMHC }\end{array}$ & $\begin{array}{c}\mathbf{T}_{\mathbf{3}}=80 \% \\
\text { of AMHC }\end{array}$ & $\begin{array}{c}\mathbf{T}_{\mathbf{4}}=70 \% \\
\text { of AMHC }\end{array}$ & $\begin{array}{c}\mathbf{T}_{\mathbf{5}}=60 \% \\
\text { of AMHC }\end{array}$ & $\begin{array}{c}\mathbf{T}_{\mathbf{6}}=50 \% \\
\text { of AMHC }\end{array}$ \\
\hline Yield (g/plant) & 106.25 & 171.25 & 127.50 & 75 & 55 & 40.75 \\
\hline $\begin{array}{c}\text { Water consumed } \\
\text { (mm plant }^{-1} \text { ) }\end{array}$ & 211.98 & 243.02 & 225.78 & 155.09 & 135.51 & 105.62 \\
\hline $\begin{array}{c}\text { Water use } \\
\text { efficiency (g mm }\end{array}$ & 0.50 & 0.70 & 0.56 & 0.48 & 0.41 & 0.39 \\
\hline
\end{tabular}

Table.6 Mean Kc, ETo and ETc (T2 at $90 \%$ of AMHC) at various growth stages

\begin{tabular}{|c|c|c|c|}
\hline Growth stages & Kc & ETo $(\mathrm{mm} /$ day $)$ & ETc (mm/day) \\
\hline Initial stage & 0.44 & 2.23 & 0.99 \\
\hline Developmental stage & 0.78 & 3.04 & 2.34 \\
\hline Mid stage & 0.98 & 2.60 & 2.52 \\
\hline Harvest stage & 0.60 & 2.63 & 1.66 \\
\hline
\end{tabular}

The developed $\mathrm{K}_{\mathrm{c}}$ values for groundnut crop under different levels of Available moisture holding capacities at different crop growth stages namely, initial, developmental, mid and late stages were presented. The Kc value of $\mathrm{T} 2$ is the highest as compared to the other treatments and these values are found to be in concurrence with the FAO $\mathrm{K}_{\mathrm{c}}$ values for groundnut crop. The observed $\mathrm{K}_{\mathrm{c}}$ values in case of 10 per cent depletion of soil moisture level $\left(\mathrm{T}_{2}\right)$ was on par with the FAO suggested $\mathrm{K}_{\mathrm{c}}$ value for groundnut crop.

The results show that deficit irrigation is infeasible. However, to a large extent when water given is below $80 \%$ of $\mathrm{AMHC}$, it negatively affects growth, development and total yield or profitability of groundnut production in the north eastern dry zone (Raichur) of Karnataka. From this experiment it can be concluded that a $10-15 \%$ reduction in the amount or volume of water required while all other things been equal could be the best condition for groundnut production if water economics is to be practiced to improve net profit of production. Finally the crop coefficient Kc values for the north eastern dry zone (Raichur) of Karnataka are between 0.44-0.98.

\section{Acknowledgements}

We are most grateful to the Department of Agricultural Engineering, College of Agriculture engineering Raichur, Karnataka (University of Agricultural science) for their financial support. We also sincerely appreciate Satish kumar U, Ayyana Gowdar M. S, Srinivasa Reddy G. V and Shanwad U. $\mathrm{K}$ for their assistance during the experiment.

\section{References}

Allen, G. R., Pereira, S. L., Raes, D. and Smith, M. (1998). Crop Evapotranspiration. Guidelines for computing crop water requirement FAO Irrigation and drainage paper 56, Rome.

Ashley, D. A., Doss, B. D. and Bennett, O. L., (1965). Relation of cotton leaf area index to plant growth and fruiting. Agron. J., 57: 61-67.

Hervey, D., Fabre, F., Berrios, E. F., Leroux, N., Chaarani, G. A., Planchon, C., 
Sarrafi A. and Gentzbittel, L., (2001). QTL analysis of photosynthesis and water status traits in sunflower (Helianthus annuus L.) under greenhouse conditions. J. Exp. Bot., 52: 1857-1864.

Jackson, M, L., (1967). Soil chemical analysis, Prentice Hall of India Pvt. Ltd., New Delhi.

Norman, M. J. T., Pearson, C. J., and Searle, P. G. E. (1995). The ecology of tropical food crop 2nd Ed. Cambridge University Press. U. K.

Piper, C. S., (1996). Soil Analyzer, Academics Press, New York, pp. 152158.

Richards, L. A., (1954). Diagnosis and improvement of saline alkali soils. Agriculture hand book, No. 60, US,
Department of Agriculture, Washington.

Savage, G.P, and Keenan, J.I. (1994). The Composition and Nutritive Value of Groundnut Kernels. ln: Smart J(ed). The Groundnut Crop: Scientific basis for improvement. London: Chapman and Hall, pp.173- 213

Sinclair, T. R., Tanner, C. B. and Bennett, J. M., (1984). Water-Use Efficiency in Crop Production. American Institute of Biological Sciences, 34: 36-40.

Teng, S., Quian, Q., Zheng, D., Kunihiro, Y., Fujimoto, K., Huang, D. and Zhu, L., (2004). Quality analysis of leaf photosynthetic rate and related traits in rice (Oryza sativa L.). Euphytica, 135: $1-7$.

\section{How to cite this article:}

Aruna, K.T., U. Satish Kumar, G.V. Srinivasa Reddy, A. Amare Gowda and U.K. Shanwad. 2017. Water Use Efficiency, Yield and Crop Coefficient (Kc) of Groundnut Crop at Different Water Regimes under Agro Climatic Condition of Raichur, Karnataka, India. Int.J.Curr.Microbiol.App.Sci. 6(12): 1956-1963. doi: https://doi.org/10.20546/ijcmas.2017.612.223 